\title{
MUATAN NILAI-NILAI KARAKTER PADA BUKU TEKS KURIKULUM 2013 PEGANGAN GURU DAN PEGANGAN SISWA KELAS II
}

\author{
Atikah Mumpuni dan Muhsinatun Siasah Masruri \\ Pascasarjana Universitas Negeri Yogyakarta \\ email: atikahmumpuni@gmail.com
}

\begin{abstract}
Abstrak: Penelitian ini bertujuan untuk mendeskripsikan: (1) nilai-nilai karakter; (2) kesesuaian nilai karakter terhadap indikator KI 1 dan KI 2; serta (3) teknik penyajian nilai karakter pada buku teks Kurikulum 2013 pegangan guru dan pegangan siswa kelas II SD semester satu. Penelitian ini merupakan penelitian analisis konten yang dilaksanakan melalui enam tahap, yaitu: (1) pengumpulan data; (2) penentuan sampel; (3) pencatatan data; (4) reduksi; (5) penarikan kesimpulan; dan (6) mendeskripsikan hasil penelitian. Sumber data dalam penelitian ini adalah Buku Teks Kurikulum 2013 kelas II SD semester satu terbitan Kemdikbud yang terdiri atas empat tema. Sebagai objek penelitian adalah muatan nilai-nilai karakter yang terkandung dalam buku tersebut. Hasil penelitian menunjukkan bahwa: (1) buku pegangan guru dan buku pegangan siswa dalam setiap tema mengandung muatan nilainilai karakter dengan jumlah bervariasi dan persebaran kurang merata; (2) nilai karakter yang disajikan sebagian besar telah sesuai dengan indikator KI 1 dan KI 2, tetapi ditemukan pula karakter di luar indikator tersebut; (3) teknik penyajian nilai-nilai karakter yang sesuai indikator KI 1 dan KI 2 dengan cara: (a) pengungkapan dan pengintegrasian nilai karakter; (b) menggunakan lagu, cerita, dan drama untuk memunculkan nilai karakter; (c) mengubah hal-hal negatif menjadi positif; serta (d) melakukan praktik lapangan untuk memunculkan nilai karakter.
\end{abstract}

Kata Kunci: nilai-nilai karakter, buku teks, Kurikulum 2013, sekolah dasar

\section{THE CHARACTER VALUES IN THE 2013 CURRICULUM TEACHER'S HANDBOOK AND STUDENT'S HANDBOOK FOR THE SECOND GRADE OF ELEMENTARY SCHOOL}

\begin{abstract}
This study is aimed to describe: (1) the character values; (2) the suitability of the character with the indicators of KI 1 and KI 2; and (3) presentation technique of the character values in the 2013 curriculum teacher's handbook and student's handbook for the second grade students of elementary school in their first semester. This research is a content analysis study conducted with a six-step technique consisting of: (1) data collection; (2) sampling; (3) recording of data; (4) data reduction; (5) conclusion drawing; and (6) describing the results of the research. The data resources were the 2013 curriculum text books for the second grade students of elementary school in the first semester, published by the Ministry of Education and Culture. The objects of the research were the character values contained in the books. The results of this study indicate that: (1) the teacher's handbook and student's handbook within each theme contain loads of character values with varying amounts and uneven distribution; (2) the character values presented are mostly in accordance with the indicators of KI 1 and KI 2, but there are also character values beyond the indicators of KI 1 and KI 2; (3) the presentation technique of the character values which are in line with the indicators of KI 1 and KI 2 is by way of: (a) disclosing and integrating the character values; (b) using songs, stories, and drama to expose the character values; (c) changing the negatives into positives; and (d) the field practice to reveal the character values.
\end{abstract}

Keywords: character values, text book, Curriculum 2013, elementary school

\section{PENDAHULUAN}

Kurikulum pendidikan di Indonesia seperti halnya di negara lain, selalu ditinjau ulang tiap 10 tahunan. Hasil peninjauan ulang terakhir menghasilkan Kurikulum 2013. Pada tahun ajaran 2014/2015, Kurikulum 2013 sempat diterapkan secara serentak di seluruh Indonesia selama satu 
semester, yaitu di semester pertama. Pada semester berikutnya, sekolah-sekolah yang baru satu semester menerapkan Kurikulum 2013 yaitu pada semester pertama tahun ajaran 2014/2015 kembali menggunakan Kurikulum 2006. Sementara itu, sekolahsekolah yang telah menerapkan Kurikulum 2013 selama tiga semester tetap menggunakan Kurikulum 2013. Dengan demikian, saat ini di Indonesia terdapat dua kurikulum pendidikan yang digunakan (Peraturan Menteri Pendidikan dan Kebudayaan No. 160 Tahun 2014 tentang Pemberlakuan Kurikulum Tahun 2006 dan Kurikulum 2013).

Pada Kurikulum 2013, setiap jenjang pendidikan telah ditentukan materi dan kompetensi minimal yang harus dicapai. Peraturan Menteri Pendidikan dan Kebudayaan No. 64 Tahun 2013, tentang Standar Isi Pendidikan Dasar dan Menengah, Pasal 1 ayat 1, menegaskan bahwa Standar Isi untuk Pendidikan Dasar dan Menengah yang selanjutnya disebut Standar Isi mencakup lingkup materi minimal dan tingkat kompetensi minimal untuk mencapai kompetensi lulusan minimal pada jenjang dan jenis pendidikan tertentu.

Dalam lampiran peraturan tersebut, setiap tingkat kelas dikelompokkan berdasarkan tingkat kompetensi 0 sampai dengan 6. Siswa Sekolah Dasar berada pada tingkat kompetensi 1 sampai dengan 3 . Kompetensi yang harus dicapai setiap tingkatannya, meliputi sikap spiritual, sikap sosial, pengetahuan, dan keterampilan. Separuh dari kompetensi yang harus dicapai yaitu kompetensi spiritual dan kompetensi sosial berkaitan dengan nilai-nilai karakter. Oleh sebab itu, dapat dikatakan bahwa Kurikulum 2013 sebagai kurikulum yang menekankan pada pengembangan karakter siswa.
Lickona menegaskan, "Character is having the right stuff" (Lickona, 2004, p.6). Karakter terdiri atas nilai-nilai kebajikan yang digunakan sebagai pedoman dalam berperilaku. Karakter sebagai kepribadian yang terbentuk dari kebajikan digunakan sebagai landasan dalam berpikir, bersikap, dan bertindak. Apabila kebajikan digunakan dalam segala hal, maka tindakan tidak akan melanggar norma atau aturan. Sebaliknya, penyimpangan kebajikan akan memunculkan tindakan yang cenderung melanggar aturan sehingga mengantarkan pada kehidupan yang tidak tertib dan tidak terkendali.

Nilai-nilai karakter dikembangkan untuk menghasilkan siswa yang baik perilakunya. Rawana, Franks, Brownlee, Rawana, \& Neckoway (2011:127) menyatakan, "Character education programs have gained increasing interest in the past decade and are designed to produce students who are thoughtful, ethical, morally responsible, community oriented, and self-disciplined." Kebaikan perilaku yang dimaksud diwujudkan dalam kepribadian yang bijaksana, beretika, bermoral, bertanggung jawab, yang berorientasi pada masyarakat, dan disiplin diri.

Nilai karakter dapat membentuk manusia secara utuh. Hal ini disebabkan nilai karakter merupakan penyeimbang atas pengetahuan yang dimiliki oleh seorang siswa. Nilai karakter merupakan salah satu upaya dalam membentuk manusia secara utuh (holistik) yang berkarakter, yaitu mengembangkan aspek fisik, emosi, sosial, kreativitas dan intelektual secara optimal (Sri Muryaningsih \& Mustadi, 2015, p.193). Harapannya, dengan nilai karakter siswa dapat memanfaatkan pengetahuan yang dimilikinya untuk hal-hal yang positif.

Nilai karakter sebagai bagian dari karakter disampaikan melalui pendidikan karakter. Pendidikan karakter saat ini se- 
dang gencar dilakukan karena terdapat indikasi penurunan nilai karakter pada generasi muda. Indikasi penurunan karakter ini didukung oleh berita-berita seperti pencurian dan kekerasan yang dilakukan oleh siswa Sekolah Dasar. Beberapa waktu lalu, berita tanah air kita dihebohkan dengan berita kekerasan yang dilakukan oleh anak Sekolah Dasar di Bukit Tinggi. Diceritakan dalam kasus tersebut bahwa seorang siswi kelas $\mathrm{V}$ dipukul oleh dua orang siswa dan satu siswi temannya. Kasus kekerasan ini terjadi lantaran salah seorang siswa yang memukul merasa sakit hati karena ibunya dihina oleh siswi yang dipukul tersebut (Republika online, edisi 12 Oktober 2014).

Pendidikan karakter perlu dilakukan, agar dapat memberikan dampak positif dalam kehidupan manusia. Pengaruh positif dari pendidikan karakter dapat dijadikan bekal bagi kehidupan siswa di kemudian hari. Dwiningrum (2013:145) mengungkapkan, "Character education is expected to overcome the crisis that occurred in the character of the global community and play a role in developing human potential optimally as well as develop patterns of thought and behavior of students who are responsible for the conduct of social roles in the family, society and citizens." Pendidikan karakter diharapkan dapat mengatasi krisis yang terjadi dalam karakter masyarakat global dan mengembangkan potensi manusia secara optimal serta mengembangkan pola pikir dan perilaku siswa yang bertanggung jawab atas pelaksanaan peran sosial dalam keluarga, masyarakat, dan sebagai warga negara.

Pendidikan karakter juga berperan dalam menjaga kemerdekaan dan kedaulatan bangsa. Pendidikan karakter merupakan proses untuk mengembangkan pada diri setiap siswa kesadaran sebagai warga negara bangsa yang bermartabat, merdeka dan berdaulat, serta memiliki kemauan untuk menjaga dan mempertahankan kemerdekaan dan kedaulatan bangsa (Zamroni, 2011:159). Maka, pendidikan karakter membantu terbentuknya warga negara yang berkarakter baik. Warga negara yang berkarakter baik akan mengantarkan negara yang ditempatinya menjadi baik pula.

Pelaksanaan pendidikan karakter di sekolah perlu didukung dengan berbagai sarana dan prasarana. Hasil penelitian menunjukkan pendidikan karakter perlu didukung oleh pengetahuan mengenai karakter dan pengelolaan sarana pendukung (Darmayanti \& Wibowo, 2014:223). Buku teks merupakan salah satu sarana pendukung dalam rangka mengembangkan karakter siswa.

Buku teks akan sering dibaca oleh siswa, sehingga buku teks dapat mempengaruhi perkembangan siswa, termasuk karakternya. Oleh sebab itu, buku teks dapat dikatakan sebagai media yang strategis untuk mengembangkan karakter siswa. Buku dapat mempengaruhi perkembangan minat, sikap sosial, emosi, dan penalaran siswa. Buku teks yang berisi hal-hal positif, termasuk karakter yang baik akan turut serta mempengaruhi perkembangan ke arah yang positif dalam diri siswa (Muslich, 2010:20).

Buku teks Kurikulum 2013 sebagai bentuk jabaran Kurikulum 2013 merupakan media efektif dalam mengembangkan karakter siswa. Peraturan Menteri Pendidikan Nasional No. 2 Tahun 2008, tentang Buku Teks, pada Pasal 1 ayat 3, menegaskan bahwa buku teks pelajaran pendidikan dasar, menengah, dan perguruan tinggi yang selanjutnya disebut buku teks adalah buku acuan wajib untuk digunakan di satuan pendidikan dasar dan menengah atau perguruan tinggi yang memuat materi pelajaran dalam rangka meningkatkan ke- 
imanan, ketakwaan, akhlak mulia dan kepribadian, penguasaan ilmu pengetahuan dan teknologi, peningkatan kepekaan dan kemampuan estetis, peningkatan kemampuan kinetis dan kesehatan yang disusun berdasarkan standar nasional pendidikan. Memperhatikan isi Peraturan Menteri Pendidikan Nasional tersebut, fungsi dari buku teks pada dasarnya tidak hanya berisi tentang materi pelajaran. Buku teks juga sebagai media mengembangkan karakter dalam diri siswa. Oleh sebab itu, buku teks dapat mengantarkan siswa cakap ilmu yang diimbangi dengan kepribadian yang baik.

Buku teks Kurikulum 2013, yang terdiri atas buku guru dan buku siswa diterbitkan secara terpusat oleh pemerintah sebagai bentuk pengawasan isi buku. Pengawasan tersebut diharapkan dapat meminimalkan terjadinya ketidaksesuaian isi buku yang mengakibatkan buku-buku teks pelajaran ditarik ulang. Berita-berita tentang buku teks pelajaran yang ditarik ulang sempat meresahkan dunia pendidikan beberapa tahun terakhir. Sebagai contoh, berita yang ditulis oleh Permana (2013), tentang buku pelajaran yang berbau porno. Buku yang dimaksud adalah Buku Bahasa Indonesia untuk kelas VI Sekolah Dasar yang digunakan di SDN Gunung Geude Kota Bogor. Buku berjudul "Aku Senang Bahasa Indonesia", diterbitkan oleh CV Graphia Buana memuat cerita yang tidak sepantasnya. Pada cerita yang berjudul "Anak Gembala dan Induk Srigala", didapati isi cerita yang mengarah pada bacaan dewasa (Koran Tempo Online, edisi 11 Juli 2013).

Pengembangan karakter dalam buku teks Kurikulum 2013 mengacu pada kompetensi spiritual dan kompetensi sosial yang terdapat pada (lampiran) Peraturan Menteri Pendidikan dan Kebudayaan No- mor 64 Tahun 2013, tentang Standar Isi Pendidikan Dasar dan Menengah. Kompetensi spiritual mencerminkan karakter religius, sedangkan kompetensi sosial terdiri atas beberapa nilai sesuai dengan tingkat kelasnya. Adapun deskripsi kompetensi sosial pada kelas II sesuai dengan Permendikbud tersebut adalah, "Menunjukkan perilaku jujur, disiplin, tanggung jawab, santun, peduli, dan percaya diri dalam berinteraksi dengan keluarga, teman, dan guru."

Buku teks kelas rendah memiliki potensi yang lebih besar dalam pengembangan nilai-nilai karakter. Fokus pembangunan pendidikan tahun 2010-2014 dalam naskah Kementerian Pendidikan dan Kebudayaan (2013) menegaskan bahwa pendidikan karakter lebih banyak difokuskan pada kelas rendah. Kelas rendah yang dimaksud adalah kelas I, II, dan III Sekolah Dasar. Tahun ajaran 2014/2015, pada kelas II Kurikulum 2013 pertama kali diterapkan, serentak secara nasional. Oleh sebab itu, analisis buku untuk kelas II masih perlu dilakukan agar nilai-nilai karakter yang hendak dikembangkan tidak ada yang terlewat.

Analisis muatan nilai karakter dilakukan pada buku teks Kurikulum 2013 kelas II semester satu Sekolah Dasar, yang terdiri atas empat tema. Tema-tema tersebut sesuai dengan (lampiran) Peraturan Menteri Pendidikan dan Kebudayaan Nomor 51 Tahun 2014, tentang Buku Teks Pelajaran dan Buku Panduan Guru untuk Pendidikan Dasar dan Pendidikan Menengah, yang terdiri atas tema (1) hidup rukun; (2) bermain di lingkunganku; (3) tugasku sehari-hari; dan (4) aku dan sekolah$\mathrm{ku}$. Keempat tema inilah yang menjadi dasar siswa dalam berinteraksi dengan orang lain. Tema-tema tersebut mengajarkan tentang sikap yang harus dilakukan terhadap sesama dan lingkungannya. Tentu dengan tidak melupakan tugas-tugas dalam ke- 
hidupan, sekaligus mengenalkan sekolah sebagai miniatur masyarakat.

Penelitian ini bertujuan (1) mengidentifikasi nilai-nilai karakter yang termuat dalam seluruh komponen buku teks Kurikulum 2013 pegangan guru dan pegangan siswa kelas II semester satu Sekolah Dasar; (2) menganalisis kesesuaian nilai-nilai karakter yang terdapat pada buku teks Kurikulum 2013 pegangan guru dan buku pegangan siswa kelas II semester satu sekolah dasar terhadap indikator KI 1 dan KI 2; dan (3) mengidentifikasi teknik penyajian nilai-nilai karakter di dalam buku teks Kurikulum 2013 pegangan guru dan pegangan siswa kelas II semester satu sekolah dasar.

Penelitian ini diharapkan dapat menghasilkan saran-saran yang dapat digunakan sebagai acuan peningkatan karakter melalui model integrasi di dalam materi pelajaran untuk Sekolah Dasar. Selain itu, penelitian ini juga diharapkan dapat memberikan masukan kepada penulis buku dan digunakan sebagai acuan bagi pengguna buku.

\section{METODE}

Penelitian ini merupakan penelitian analisis konten yang terdiri atas enam langkah, yaitu pengumpulan data, menentukan sampel, perekaman atau pencatatan, reduksi, penarikan kesimpulan, dan mendeskripsikan (Krippendorff, 2013, p.84). Buku teks yang dianalisis adalah buku teks Kurikulum 2013 terbitan Kementrian Pendidikan dan Kebudayaan. Buku teks tersebut telah digunakan di sekolah pilot project di Kota Yogyakarta. Penelitian ini dilaksanakan pada bulan November 2015 sampai dengan Januari 2016.

Sumber data dalam penelitian ini adalah buku teks Kurikulum 2013 pegangan guru dan pegangan siswa kelas II semester satu sekolah dasar yang diterbitkan oleh Kemdikbud. Buku-buku tersebut memuat tema "Hidup Rukun", "Bermain di Lingkunganku", "Tugasku Sehari-Hari", serta "Aku dan Sekolahku". Objek penelitian ini adalah muatan nilai-nilai karakter yang terkandung dalam seluruh bagian buku.

Pengumpulan data dalam penilitian ini dilakukan dengan analisis dan pencatatan secara cermat terhadap buku teks pelajaran Kurikulum 2013 pegangan guru dan pegangan siswa kelas II semester satu Sekolah Dasar. Instrumen utama dalam penelitian ini adalah human instrument yaitu peneliti sendiri, dengan cara memasukkan dalam rubrik analisis yang disusun berdasarkan landasan teori terkait nilai-nilai karakter.

Keabsahan data dalam penelitian ini menggunakan validitas dan reliabilitas. Validitas yang digunakan dalam penelitian ini adalah "validitas semantik". Validasi dilakukan untuk mengetahui kesesuaian makna teks dengan konteks yang dipilih. Kesesuaian makna teks yang dimaksud adalah nilai-nilai karkater yang ditemukan dalam buku teks Kurikulum 2013 kelas II sekolah dasar. Sementara, konteks yang dipilih adalah nilai-nilai karakter yang sesuai dengan Peraturan Menteri Pendidikan dan Kebudayaan No. 64 Tahun 2013, tentang Standar Isi Pendidikan Dasar dan Menengah. Nilai karakter yang dimaksud terdiri atas religius, jujur, disiplin, tanggung jawab, santun, peduli, dan percaya diri.

Reliabilitas yang digunakan dalam penelitian ini adalah "reliabilitas stabilitas" dan "reliabilitas replikabilitas". Reliabilitas stabilitas dilakukan dengan pembacaan berulang terhadap data yang telah diperoleh agar mendapatkan pemahaman terhadap dokumen yang diteliti, yaitu buku teks Kurikulum 2013. Dengan demikian, dapat diperoleh data yang konsisten terkait 
muatan nilai-nilai karakter di dalam buku teks Kurikulum 2013. Sedangkan Reliabilitas replikabilitas dilakukan dengan menganalisis dokumen melalui diskusi dan konfirmasi yang dilakukan dengan dua orang teman sejawat, untuk dapat memberikan masukan terkait hasil analisis sehingga data yang diperoleh menjadi lebih objektif.

\section{HASIL DAN PEMBAHASAN Hasil Penelitian}

Buku kelas II semester satu yang dianalisis muatan nilai karakternya, terdiri atas empat tema. Keempat tema tersebut adalah tema hidup rukun, bermain di lingkunganku, tugasku sehari-hari, serta tema aku dan sekolahku. Tema-tema tersebut, terdiri atas buku pegangan guru dan buku pegangan siswa. Setiap tema memiliki fokus pengembangan nilai karakter. Karakter yang menjadi fokus pengembangan akan dinilai dan diamati perkembangannya. Selain fokus pengembangan nilai karakter tersebut, setiap tema juga ditemukan nilainilai karakter yang sesuai maupun yang tidak sesuai dengan indikator KI 1 dan KI 2.

\section{Muatan Nilai-nilai Karakter pada Tema Hidup Rukun}

Tema hidup rukun adalah tema pertama yang disajikan di semester satu kelas II sekolah dasar. Buku pegangan guru dan buku pegangan siswa dalam tema ini memuat empat subtema. Keempat subtema tersebut meliputi, hidup rukun di rumah, hidup rukun dengan teman bermain, hidup rukun di sekolah, dan hidup rukun di masyarakat. Nilai karakter yang akan dikembangkan dalam tema hidup rukun adalah percaya diri, santun, dan teliti. Dua karakter pertama yang disebutkan, yaitu percaya diri dan santun merupakan karakter yang sesuai dengan indikator KI 2. Satu karakter terakhir yang tertulis, yaitu teliti merupakan karakter yang tidak sesuai dengan indikator KI 1 dan KI 2. Di samping fokus pengembangan karakter tersebut, dalam tema ini juga ditemukan karakter lain baik yang sesuai maupun yang tidak sesuai dengan indikator KI 1 dan KI 2.

Pada umumnya, karakter yang disajikan dalam buku guru dan buku siswa tema hidup rukun, sebagian besar sudah sesuai dengan indikator KI 1 dan KI 2. Nilai karakter yang ditemukan sesuai dengan indikator KI 1 dan KI 2 meliputi religius, jujur, disiplin, tanggung jawab, santun, peduli, dan percaya diri. Karakter-karakter tersebut, tersebar dalam seluruh bagian buku guru dan buku siswa dengan persebaran yang kurang merata dan jumlah bervariasi. Karakter lain yang tertulis di luar indikator KI 1 dan KI 2 meliputi sportif, toleransi, kasih sayang, cermat, kerja sama, dan teliti. Karakter yang sesuai dengan indikator KI 1 dan indikator KI 2 disajikan dengan teknik penyajian yang bervariasi. Teknik penyajian tersebut, di antaranya dilakukan dengan (1) pengungkapan nilai karakter; (2) pengintegrasian nilai karakter, menggunakan lagu; dan (3) menggunakan cerita untuk memunculkan nilai karakter.

\section{Muatan Nilai-nilai Karakter pada Tema Bermain di Lingkunganku}

Tema kedua yang disajikan dalam semester satu kelas II sekolah dasar adalah tema bermain di lingkunganku. Buku pegangan guru dan buku pegangan siswa dalam tema ini terdiri atas empat subtema. Keempat subtema tersebut, yaitu subtema bermain di lingkungan rumah, bermain di rumah teman, bermain di lingkungan sekolah, dan bermain di tempat wisata. Nilai karakter yang menjadi fokus pengembangan dalam tema ini, yaitu cermat, tanggung jawab, dan percaya diri. Dua karakter terakhir yang disebutkan, yaitu tanggung ja- 
wab dan percaya diri adalah karakter yang sesuai dengan indikator KI 2. Cermat adalah karakter yang tidak sesuai dengan indikator KI 1 maupun KI 2. Selain ketiga karakter yang menjadi fokus pengembangan, pada buku pegangan guru maupun buku pegangan siswa juga ditemukan karakter lain, baik yang sesuai maupun yang tidak sesuai dengan indikator KI 1 dan KI 2.

Buku pengangan guru dan buku pegangan siswa tema bermain di lingkunganku pada umumnya menyajikan karakter yang sesuai dengan indikator KI 1 dan KI 2. Karakter tersebut yang meliputi religius, jujur, disiplin, tanggung jawab, santun, peduli, dan percaya diri disajikan secara lengkap dengan persebaran yang kurang merata dan jumlah bervariasi. Di samping itu, ditemukan pula karakter yang kurang sesuai dengan indikator KI 1 dan KI 2, meliputi cermat, teliti, toleransi, tidak mudah menyerah, kasih sayang, dan rasa ingin tahu. Nilai karakter yang sesuai dengan KI 1 dan KI 2 disajikan dengan teknik penyajian yang bervariasi, meliputi (1) pengintegrasian nilai karakter; (2) melakukan praktik lapangan; dan (3) menggunakan cerita, drama, dan lagu untuk memunculkan nilai karakter.

\section{Muatan Nilai-nilai Karakter pada Tema Tugasku Sehari-Hari}

Tema tugasku sehari-hari merupakan tema ketiga yang disajikan di kelas II, semester satu sekolah dasar. Buku pegangan guru dan buku pegangan siswa pada tema ini, terdiri atas empat subtema, yang terdiri dari tema tugasku sehari-hari di rumah, tugasku sehari-hari di sekolah, tugasku sebagai umat beragama, dan tugasku dalam kehidupan sosial. Fokus pengembangan karakter pada tema tugasku sehari-hari adalah disiplin, percaya diri, dan cermat. Dua karakter yang disebut pertama, yaitu di- siplin dan percaya diri, merupakan karakter yang sesuai dengan indikator KI 2. Cermat merupakan karakter yang tidak sesuai dengan indikator KI 1 maupun KI 2. Pada tema tugasku sehari-hari juga ditemukan karakter lain di luar karakter yang menjadi fokus pengembangan.

Karakter yang disajikan dalam buku pegangan guru tema tugasku sehari-hari, pada umumnya telah sesuai dengan indikator KI 1 dan KI 2 terdiri atas religius, jujur, disiplin, tanggung jawab, santun, peduli, dan percaya diri. Karakter-karakter tersebut, tersebar dengan persebaran yang kurang merata dan jumlah bervariasi. Di samping itu, ditemukan pula karakter di luar indikator KI 1 dan KI 2 yang meliputi, cermat, teliti, tidak mudah menyerah, rasa ingin tahu, toleransi, dan kasih sayang. Karakter yang sesuai dengan indikator KI 1 dan KI 2 disajikan dengan teknik penyajian yang bervariasi, meliputi: (1) pengintegrasian nilai karakter dalam materi; (2) menggunakan cerita, lagu, dan drama untuk memunculkan nilai karakter; dan (3) mengubah hal-hal negatif menjadi positif.

\section{Muatan Nilai-nilai Karakter pada Tema Aku dan Sekolahku}

Tema aku dan sekolahku, merupakan tema keempat atau tema terakhir dalam semester satu kelas II sekolah dasar. Buku pegangan guru dan buku pegangan siswa dalam tema ini terdiri atas empat subtema, yaitu tugas-tugas sekolahku, kegiatan ekstrakurikulerku, lingkungan sekolahku, dan prestasi sekolahku. Fokus pengembangan nilai karakter pada tema ini adalah percaya diri, santun, dan teliti. Dua karakter pertama yang disebutkan yaitu percaya diri dan santun merupakan karakter yang sesuai dengan indikator KI 2. Karakter terakhir yang disebut, yaitu teliti, merupakan 
karakter yang tidak sesuai dengan KI 1 dan KI 2.

Nilai karakter yang ditemukan dalam buku pegangan guru dan buku pegangan siswa tema "Aku dan Sekolahku", pada umumnya telah sesuai dengan indikator KI 1 dan KI 2. Nilai karakter yang sesuai terdiri atas religius, jujur, disiplin, tanggung jawab, santun, peduli dan percaya diri. Ketujuh karakter tersebut tersebar dalam bagian buku pegangan guru dan buku pegangan siswa dengan persebaran yang tidak merata. Di samping itu, ditemukan pula nilai karakter lain di luar indikator KI dan KI 2, meliputi sportif, cermat, teliti, tidak mudah menyerah, toleran, dan rasa ingin tahu. Karakter yang sesuai dengan indikator KI 1 dan KI 2 disajikan dengan teknik penyajian yang bervariasi, meliputi (1) pengintegrasian nilai karakter dalam materi; (2) mengungkapkan nilai karakter; dan (3) menggunakan lagu, drama, dan cerita untuk memunculkan nilai karakter.

\section{Pembahasan}

Nilai-nilai karakter yang sesuai dengan Peraturan Menteri Pendidikan dan Kebudayaan No. 64 Tahun 2013 tentang Standar Isi Pendidikan Dasar dan Menengah dideskripsikan jumlah dan persebarannya. Karakter tersebut, terdiri atas religius, jujur, disiplin, tanggung jawab, santun, peduli, dan percaya diri ditemukan dengan persebaran yang kurang merata. Kemunculan nilai karakter dalam setiap tema dipengaruhi oleh fokus pengembangan karakter. Karakter yang menjadi fokus pengembangan, khususnya dalam buku pegangan guru akan banyak disebut dalam tujuan pembelajaran sehingga mendongkrak kemunculan nilai karakter yang akan dikembangkan. Selain itu, tema-tema yang disajikan juga mempengaruhi kemunculan nilai karakter. Misalnya, nilai karakter re- ligius banyak dijumpai dalam tema tugasku sehari-hari, subtema tugasku sebagai umat beragama.

Berdasarkan hasil analisis yang telah dilakukan, jumlah nilai karakter yang ditemukan sebanyak 2082. Jumlah tersebut merupakan akumulasi dari semua tema yang terdiri atas tema "Hidup Rukun", "Bermain di Lingkunganku", "Tugasku SehariHari", serta "Aku dan Sekolahku". Adapun rincian jumlah nilai setiap karakter yaitu: (1) religius 243; (2) jujur 61; (3) disiplin 209; (4) tanggung jawab 245; (5) santun 237; (6) peduli 154; dan (7) percaya diri 933.

Berdasarkan data tersebut, dapat diketahui terdapat tiga nilai karakter yang menduduki urutan teratas berdasarkan frekuensi kemunculannya. Ketiga nilai karakter tersebut adalah religius, tanggung jawab, dan percaya diri. Ketiga karakter tersebut merupakan karakter-karakter yang yang diharapkan berkembang pada siswa Sekolah Dasar sesuai dengan Standar Kompetensi Lulusan dalam Peraturan Menteri Pendidikan dan Kebudayaan No. 54 Tahun 2013, tentang Standar Kompetensi Lulusan Pendidikan Dasar dan Menengah. Dalam permendikbud tersebut, dijelaskan mengenai kualifikasi kemampuan siswa Sekolah Dasar untuk masing-masing dimensi, yaitu dimensi sikap, pengetahuan, dan keterampilan. Dimensi sikap adalah dimensi yang berkaitan dengan karakter.

Adapun kualifikasi dimensi sikap untuk siswa sekolah dasar, yaitu memiliki perilaku yang mencerminkan sikap orang beriman, berakhlak mulia, berilmu, percaya diri, dan bertanggung jawab dalam berinteraksi secara efektif dengan lingkungan sosial dan alam di lingkungan rumah, sekolah, dan tempat bermain (Lampiran Peraturan Menteri Pendidikan Nasional No. 54 Tahun 2013, tentang Standar Kompetensi Lulusan Pendidikan Dasar 
dan Menengah). Orang beriman dan berakhlak mulia pada kualifikasi kemampuan dimensi sikap mencerminkan karakter religius. Kata percaya diri dan bertanggung jawab disebut secara tersurat pada kualifikasi kemampuan dimensi sikap.

Setiap tema menyajikan nilai karakter secara lengkap sesuai dengan indikator KI 1 dan KI 2. Nilai karakter yang sesuai tersebut meliputi religius, jujur, disiplin, tanggung jawab, peduli, santun, dan percaya diri. Karakter-karakter yang tidak sesuai dengan indikator meliputi: teliti, kasih sayang, kerja sama, menghargai, cermat, toleransi, tidak mudah menyerah, rasa ingin tahu, dan sportif.

Karakter-karakter di luar indikator KI 1 dan KI 2 masih termasuk dalam karakter baik. Karakter teliti, cermat, dan kasih sayang merupakan beberapa karakter yang dirumuskan dengan mengadopsi dan mengadaptasi dari Al-Asmaul Husna (Thohir, 2015). Al-Asmaul Husna adalah 99 sifat yang dimiliki oleh Allah SWT. Oleh sebab itu, secara otomatis karakter yang diadopsi dan diadaptasi dari sifat-sifat Sang Pencipta adalah karakter baik. Dengan berpedoman pada dasar Al-Asmaul Husna, Ginanjar (2008), juga merumuskan 7 spiritual core values yang salah satunya adalah kerja sama.

Karakter yang tidak sesuai lainnya, disebut baik secara tersirat maupun tersurat dalam rumusan nilai karakter dan budaya bangsa. Kemdiknas (2010a) mencantumkan 18 nilai karakter yang disusun berdasarkan kepribadian bangsa Indonesia. Lima di antaranya, meliputi menghargai, toleransi, tidak mudah menyerah, rasa ingin tahu, dan sportif.

Teknik yang penyajian nilai karakter yang terdiri atas religius, jujur, disiplin, tanggung jawab, santun, peduli, dan percaya diri bervariasi, terdiri atas: (1) peng- ungkapan nilai karakter; (2) pengintegrasian nilai karakter; (3) menggunakan lagu, cerita, dan drama untuk memunculkan nilai karakter; (4) mengubah hal-hal negatif menjadi positif; dan (5) melakukan praktik lapangan untuk memunculkan atau menemukan nilai karakter. Teknik tersebut mengacu pada desain induk pendidikan karakter yang dirumuskan oleh Kemdiknas (2010b). Dari lima teknik yang digunakan, terdapat dua teknik yang sering digunakan yaitu pengintegrasian nilai karakter serta menggunakan lagu, cerita, dan drama untuk memunculkan nilai karakter.

Nilai karakter yang disajikan, tidak berdiri sendiri sebagai suatu materi pelajaran. Nilai karakter yang hendak disampaikan diintegrasikan dalam materi pelajaran. Nilai karakter yang disajikan terintegrasi ditemukan cukup banyak dalam buku pegangan guru maupun buku pegangan siswa. Penyampaian nilai karakter pada hakekatnya tidak dapat dipisahkan dengan materi pelajaran. Nilai karakter disajikan secara terintegrasi karena memang tidak dapat dipisahkan dengan aspek lain dan merupakan landasan seluruh mata pelajaran (Hidayatullah, 2010, p.55). Hal ini dimaksudkan agar pendidikan tidak hanya membuat seorang siswa pintar, tetapi juga berkarakter. Dengan demikian, siswa dapat menggunakan ilmu yang dimilikinya untuk kebaikan.

Lagu, cerita, dan drama merupakan teknik penyajian nilai karakter dengan mengimplementasikan pembelajaran yang menyenangkan dalam diri siswa. Melalui tiga hal tersebut, siswa akan dapat lebih memahami sesuatu, termasuk menerapkan karakter dalam kehidupannya karena menerima materi dalam keadaan senang. Lagu dapat dimanfaatkan untuk menampilkan pesan dan makna positif tentang kehidupan, khususnya tentang nilai-nilai 
karakter (Kusumawati, 2013:1). Lagu-lagu yang dimaksud, tentu lagu anak-anak yang banyak ditemukan dalam buku pegangan guru dan buku pegangan siswa dalam setiap tema. Lagu yang ditemukan antara lain, "Peramah dan Sopan", "Pergi ke Sekolah", dan "Menanam Jagung".

Cerita anak juga memiliki potensi yang besar untuk menyampaikan pesan moral kepada siswa. Cerita dapat memberi kebermanfaatan karena cerita anak memiliki amanat yang mampu mengemban ajaran moral yang berupa nilai-nilai pendidikan karakter (Zubaidah, 2013:301). Siswa akan dapat menerima pesan yang disampaikan dalam cerita karena sebelum menyimpulkan pesan moral, siswa diajak terlebih dahulu untuk menikmati jalannya cerita. Dari cerita yang telah dibaca, siswa akan mengetahui hal-hal yang sebaiknya dilakukan dan hal-hal yang sebaiknya tidak dilakukan. Selanjutnya, siswa akan menarik kesimpulan mengenai pesan moral yang terkandung di dalamnya dan menerapkannya dalam kehidupan sehari-hari.

Drama menyajikan percakapan yang dapat memunculkan nilai karakter. Melalui drama, siswa tidak hanya menikmati alur cerita, tetapi juga dapat mempraktekkannya sehingga pesan moral dapat langsung diterima. Oleh sebab itu, drama dapat meningkatkan karakter siswa. Hasil penelitian menunjukkan, teknik sosiodrama dapat meningkatkan karakter siswa dalam bertata krama dengan guru dan kerapian berpakaian seragam (Rumlah, 2013:37). Drama yang digunakan untuk kelas II sekolah dasar tentu saja drama sederhana yang sarat dengan nilai-nilai karakter. Drama pada siswa kelas II sekolah dasar juga dapat disajikan dengan gambar-gambar yang mendukung tersampaikannya pesan. Komik merupakan salah satu bentuk drama yang disajikan dengan disertai gambar. Komik sebagai media pembelajaran terbukti efektif untuk meningkatkan karakter siswa (Saputro, 2015:61).

\section{PENUTUP}

\section{Simpulan}

Berdasarkan hasil penelitian dan pembahasan, dapat disimpulan seperti berikut.

- buku teks Kurikulum 2013 secara keseluruhan memuat tujuh nilai karakter sesuai dengan Peraturan Menteri Pendidikan dan Kebudayaan No. 64 Tahun 2013, tentang Standar Isi Pendidikan Dasar dan Menengah. Nilai-nilai karakter tersebut adalah religius, jujur, disiplin, tanggung jawab, peduli, santun, dan percaya diridengan persebaran yang tidak merata. Frekuensi kemunculan nilai-nilai karakter tersebut tergantung dari fokus pengembangan karakter dan tema yang disajikan.

- Nilai-nilai karakter yang tercantum dalam tema-tema yang disajikan di kelas II semester satu, sebagian besar telah sesuai dengan indikator KI 1 dan KI 2. Di samping itu, ditemukan pula nilai-nilai karakter yang tidak sesuai dengan indikator KI 1 dan KI 2, antara lain teliti, cermat, kerja sama, dan sebagainya. Namun demikian, karakter yang tidak sesuai tersebut merupakan karakter baik sehingga dapat memperkaya muatan buku guru dan buku siswa.

- Teknik penyajian nilai karakter yang disajikan dalam buku pegangan guru dan buku pegangan siswa dilakukan dengan beberapa cara, yaitu pengungkapan nilai karakter, pengintegrasian nilai karakter, menggunakan lagu, cerita, dan drama untuk memunculkan nilai karakter, mengubah hal-hal negatif menjadi positif, serta melakukan praktik lapangan untuk memunculkan nilai karakter. 


\section{Saran}

Nilai-nilai karakter yang ditemukan dalam buku Kurikulum 2013 pegangan guru dan pegangan siswa kelas II semester satu sekolah dasar telah teridentifikasi. Berdasarkan temuan dalam pembahasan tersebut, disarankan hal-hal seperti berikut.

- Guru agar: (1) mempunyai catatan penilaian karakter tersendiri, yang dapat berfungsi untuk mencatat karakter yang tidak menjadi fokus pengembangan sehingga rekam jejak perkembangan karakter siswa dapat diamati dari waktu ke waktu; dan (2) membaca pula buku pegangan siswa, sehingga pengembangan karakter seperti yang dimaksud dalam buku guru dapat disesuaikan dengan buku siswa.

- Orang tua juga agar mendampingi siswa saat belajar di rumah sehingga nilainilai karakter yang hendak dikembangkan dalam buku dapat disampaikan dan dibiasakan sejak awal.

- Siswa disarankan untuk membaca materi pelajaran dalam buku siswa sebelum mempelajari di sekolah, dan mendiskusikannya dengan orang tua terkait karakter yang hendak dikembangkan.

- Peneliti selanjutnya diharapkan dapat menganalisis muatan nilai karakter pada tema-tema yang lain sehingga nilai-nilai karakter yang hendak dikembangkan dapat teridentifikasi dengan jelas.

\section{DAFTAR PUSTAKA}

Anonim. 2014. "Bullying siswa SD Bukittiggi Terjadi saat Pelajaran Agama". (12Oktober 2014). Diambil pada tanggal 5 Juli 2015, dari http:/ / www.republika.co.id/ berita/ nasional/ hukum/ 14/ 10/ 12/ ndbt2x bullying-siswa-sd-bukittinggi-terjadi-saat-pelajaran-agama.
Darmayanti, S., \& Wibowo, U. 2014. “Evaluasi Program Pendidikan Karakter di Sekolah Dasar Kabupaten Kulon Progo". Jurnal Prima Edukasia, 2(2), 223-234.

Dwiningrum, S.I.A. 2013. “Nation's Character Education Based on the Social Capital Theory". A sian Social Science, 9(12), 144-155.

Ginanjar, A. 2008. ESQ (Emotional, Spiritual, Quetient). Jakarta: Arga.

Hidayatullah, F. 2010. Pendidikan Karakter: Membangun Peradaban Bangsa. Bandung: Yuma Pustaka.

Kemdikbud. 2013. Kebijakan dan Program Pendidikan M enengah Tahun 2013. Jakarta: Kemdikbud.

Kemdiknas. 2010a. Pengembangan Pendidikan Budaya dan Karakter Bangsa Pedoman Sekolah. Jakarta: Kementerian Pendidikan Nasional.

Kemdiknas. 2010b. Desain Induk Pendidikan Karakter. Jakarta: Kementerian Pendidikan Nasional.

Krippendorff, K. 2013. Content A nalysis an Introduction to Its M ethodology. United States of A merica: Sage.

Kusumawati, H. 2013. "Pendidikan Karakter melalui Lagu Anak-anak". Jurnal Imaji, 11(2).

Lickona, T. 2004. Character M atters: How to H elp O ur Children Develop Good Judgment, Integrity, and $O$ ther Essential V irtues. New York: Touchstone. 
Muryaningsih, S., \& Mustadi, A. 2015. “Pengembangan RPP Tematik-Integratif untuk Meningkatkan Karakter Kerja Keras di Kelas 1 SD N 2 Sokaraja Tengah". Jurnal Prima Edukasia, 3(2), $190-201$.

Muslich, M. 2010. Text Book Writing: Dasardasar Pemahaman, Penulisan, dan Pemakaian Buku Teks. Yogyakarta: Ar-Ruzz Media.

Peraturan Menteri Pendidikan dan Kebudayaan Nomor 160 Tahun 2014, tentang Pemberlakuan Kurikulum Tahun 2006 dan Kurikulum 2013.

Peraturan Menteri Pendidikan dan Kebudayaan Nomor 64 Tahun 2013, tentang Standar Isi Pendidikan Dasar dan Menengah.

Peraturan Menteri Pendidikan Nasional Nomor 2 Tahun 2008, tentang Buku.

Peraturan Menteri Pendidikan Nomor 51 Tahun 2014, tentang Buku Teks Pelajaran dan Buku Panduan Guru untuk Pendidikan Dasar dan Pendidikan Menengah.

Peraturan Menteri Pendidikan Nomor 54 Tahun 2013, tentang Standar Kompetensi Lulusan Pendidikan Dasar dan Menengah.

Permana, S. 2013. Pelajaran Porno Anak Gembala dan Induk Srigala. Diambil pada tanggal 21 Februari 2016, dari https://nasional.tempo.co/read/news.
Rawana, J.R.E., Franks, J.L., Brownlee, K., Rawana, E.P. \& Neckoway, R. 2011. "The Aplication of a Strength-Based Approach of Students' Behaviours to the Development of a Character Education Curriculum for Elementary and Secondary School". Journal of Education Thought, 45, 127-144.

Rumlah, R. 2013. “Upaya Meningkatkan Karakter Siswa melalui Layanan Bimbingan Kelompok dengan Sosiodrama". Jurnal Ilmiah Pendidikan Bimbingan dan Konseling, 1(2), 36-45.

Saputro, H., \& Soeharto, S. 2015. “Pengembangan Media Komik Berbasis Pendidikan Karakter pada Pembelajaran Tematik-Integratif Kelas IV SD". Jurnal Prima Edukasia, 3(1), 61-72.

Thohir, M. 2015. Karakter Al-Asmaul Husna: menjadi Cermin Kecil Allah. Tangerang: Lentera Hati.

Zamroni. 2011. "Strategi dan model implementasi Pendidikan Karakter di Sekolah". Dalam Darmiyati Zuchdi (Ed), Pendidikan Karakter dalam Perspektif Teori dan Praktik (Hal. 158-184). Yogyakarta: UNY Press.

Zubaidah, E. 2013. "Pemilihan Nilai Karakter dalam Cerita Anak dan Teknik Penceritaannya". Jurnal Pendidikan Anak, 2, 301-311. 